\title{
A gender-based analysis of Iranian EFL learners' types of written errors
}

\author{
Boroomand, Faezeh $\triangle S$ \\ Shahid Bahonar University of Kerman, Iran (faezeh_boroomand@yahoo.com) \\ Rostami Abusaeedi, Ali Asghar \\ Shahid Bahonar University of Kerman, Iran (rostamiabu110@yahoo.com)
}

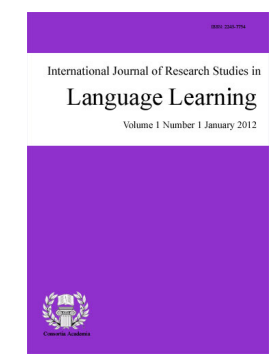

ISSN: 2243-7754 Online ISSN: 2243-7762

OPEN ACCESS

\begin{abstract}
Committing errors is inevitable in process of language acquisition and learning. Analysis of learners' errors from different perspectives, contributes to the improvement of language learning and teaching. Although the issue of gender differences has received considerable attention in the context of second or foreign language learning and teaching, few studies on the relationship between gender and EFL learners' written errors have been carried out. The present study conducted on 100 Iranian advanced EFL learners' written errors (50 male learners and 50 female learners), presents different classifications and subdivisions of errors, and carries out an analysis on these errors. Detecting the most committed errors in each classification, findings reveal significant differences between error frequencies of the two male and female groups (more error frequency in female written productions).
\end{abstract}

Keywords: error analysis; syntactic errors; processing errors; written production; EFL; ESL 


\section{A gender-based analysis of Iranian EFL learners' types of written errors}

\section{Introduction}

Language learners inevitably commit errors in the process of language learning. These errors convey messages and information about their roots, learners' language competence, and the process of language learning. Analysis of learners' errors has become an essential need to answer some questions and propose solutions regarding different aspects of language pedagogy; Therefore the field of language teaching and learning benefits from the findings of error analysis (EA) as a diagnostic tool.

In the globalization era, the ability to write well in English is a necessity for communication, educational purposes, and business cooperation. The students studying English as a second or foreign language (ESL or EFL) generally produce texts containing different types of errors. In other words English writing has always been a challenge for EFL learners, and as a vital skill, it needs to receive more attention, therefore analyzing EFL learners' errors in their written productions, can be a great help for teachers to become aware of the sources and types of these errors to employ more efficient teaching methods and strategies so that EFL learners can acquire English writing better.

As a result of researchers' interest in the issue of gender differences from different aspects, it has become the subject of many studies for many years. Gender is an influential variable in nearly all social phenomena including language, so it can be a considerable source of variation among language learners, and teachers must consider its impact on language learning (Yazdani \& Ghafar Samar, 2010).

In the field of error analysis, few studies have been conducted regarding gender differences in EFL learners' writing. Following EA procedure, the present study tends to identify and analyze the errors committed by Iranian advanced EFL learners in their written productions and the frequencies of different error types, committed by these learners, will be contrasted according to their gender.

\section{Literature Review}

\subsection{Error Analysis (EA)}

There are three approaches to errors: Contrastive Analysis (CA), Error Analysis (EA), and Interlanguage theory (IL) (Jie, 2008). In the early 1950's the notion of language as a system, and more importantly, the notion of second language acquisition as the meeting of two language systems gained more acceptance and linguists began to regard errors as evidence of language transfer. It was the time when Contrastive Analysis (CA) emerged. Until late sixties, the prominent theory regarding the issue of second language learning was behavioristic, and errors were considered as being the result of the persistence of existing mother tongue habits in the new language. This idea made the linguists pay special attention to the comparison of the native and the target language in order to manage to predict and explain errors.

In the early 1970s CA was criticized in terms of empirical, theoretical and practical considerations. Strong criticisms of CA showed that it was not as useful as it claimed to be. CA strongly emphasized that the notion of difficulty was equated with the degree of errors. Namely, the more L2 learners made errors in their acquisition of L2 the more it was assumed to be difficult and consequently the more the target and native languages were different. Another pitfall of CA was its inability in identifying sources of difficulty other than the learners' L1. Additionally CA didn't contribute to language pedagogy effectively.

Because of the drawbacks of CA, error analysis was introduced as a more vivid source of handling the 
learners' errors. Error Analysis Hypothesis was proposed by Corder (1971), who is known as the father of EA. Psychology became a much more influential field for linguists interested in using error analysis as a diagnostic tool, to help identify the causes of errors. The procedures of EA were figured out by Corder (1974) in five stages: collection of a sample of learner language, identification of errors, description of errors, explanation of errors and evaluation of errors.

Corder (1974) established an analogy between the errors produced by a child learning his/her mother tongue and those of a second or foreign language learner. He claimed that in language teaching one noticeable effect was to shift the emphasis away from teaching towards studying learning. Keshavarz (1999) divided EA into two branches: theoretical and applied. Theoretical error analysis is about the processes of first and second language learning and applied error analysis is concerned with pedagogical issues such as organizing remedial courses and devising appropriate materials and teaching strategies based on EA findings. Today error analysis is used with a variety of techniques for identifying, classifying and systematically interpreting the errors committed by language learners and it has supported hypotheses such as the natural route of development, as well as identifying the weaknesses and/or disproving theories of language learning like contrastive analysis through the last few decades. Analysis of learners' errors is an attempt to account for their origin, regularity and variability.

Corder (1967) mentioned that errors are evidence of the learners' in-built syllabus which show how L1 and L2 learners develop an independent system of language. In fact, language learners make their own language which is different from their L1 and L2 and has its own set of rules. The term interlanguage was coined by Selinker (1972) to refer to this linguistic system.

EA is a non-stop area of research (Dessouky, 1990), and will remain so because people will commit errors as long as they participate in language learning process (Mahmoud, 2011). In the last decades, many analyses have been carried out on learners' errors from different perspectives. Khodabandeh (2007) conducted an EA study on students' errors in their headline translations. The analysis of the translated English headlines revealed that the participants' chief difficulties were grammatical followed by discoursal and lexical types. It was also concluded that the participants had inadequate knowledge of the English headline rules. Darus and Subramaniam (2009) carried out an analysis on Malaysian students' errors in their essays. The results of their study showed that six most common errors committed by the participants were singular/plural form, verb tense, word choice, preposition, subject-verb agreement and word order.

Wee (2009) analyzed Malaysian ESL learners' written verb-form errors and found that errors of misformation were the highest, followed by those of omission, addition and ordering, respectively. Pena (2009) analyzed written errors committed by math, science and engineering faculty and found out that the use of tenses, preposition, noun inflection, article, subject-verb agreement and punctuation were the most committed errors respectively. Mohaghegh et al. (2011) carried out an analysis on grammatical errors committed by junior EFL students. The results of their study revealed that students had the most number of errors in preposition, relative pronoun, article, and tense respectively.

Abbasi and Karimnia (2011) also investigated grammatical errors committed by Iranian junior and senior students in their translation. The findings revealed that use of typical Persian structures, errors in the use of tenses, errors in the use of prepositions and errors in the use of articles were the most frequent errors respectively, in both junior and senior students' translation. Alhaysony (2012) conducted an analysis on Saudi learners' errors concerning the article system. She found that omission errors were the most frequent while substitution errors were the least frequent errors of this type. Jalali and Shojaei (2012) in their study on Iranian EFL learners' prepositional errors revealed that substitution errors were the most frequent errors and addition errors were the least frequent errors of this type.

While, Gustilo and Magno (2012) studied the sentence-level errors of college freshmen students at three proficiency levels and the aspects of writing that raters focused on while rating the essays. They found that the raters still have the grammar accuracy model when checking essays, although it is just considered secondary to 
other aspects of writing such as the ability to address promptly and organize the ideas logically. Nezami and Sadraie Najafi (2012) examined Iranian EFL learners' error types in their compositions at different proficiency levels. The results of analyses revealed that there were statistically significant differences among proficiency groups on overall error types and frequency of error types in each group was different.

Jabbari and Fazilatfar (2012) investigated types of Iranian learners' errors, corrective feedback moves, and learner uptake drawn from transcripts of audio-recordings of the elementary and high intermediate classes of a language institute including almost 12 hours of interaction among the students and teachers. Regarding types of errors, grammatical errors were the most frequent error type in the entire database; however, phonological and lexical errors were the least frequent errors respectively. Watcharapunyawong and Usaha (2013) analyzed writing errors caused by the interference of the Thai language, regarded as the first language (L1), in three writing genres, namely narration, description, and comparison/contrast. The results revealed that the number of frequent errors made in each type of written tasks was apparently different.

\subsection{Types of Errors}

There are different frameworks and classifications of errors according to various linguistic levels of description and systematicity, and researchers in their attempt to analyze learners' errors have developed their own categories. Halliday, McIntosh, and Strevens (1964) claimed that it is extremely useful to construct a purely descriptive framework for the analysis of errors, taking into account the level of language and the various categories involved.

Catalán (1997) tried to systematize error terms and definitions to make teachers and researchers aware of relativity of errors and the great degree of overlapping. She stated that in error studies the most appropriate terms and definitions must be chosen to serve the researchers' purposes best (ibid). Corder (1974) identified three types of errors according to their systematicity: (1) presystematic errors occur when the learner is unaware of the existence of a particular rule in the target language; (2) systematic errors occur when the learner has discovered a rule but it is a wrong one; (3) postsystematic errors occur when the learner knows the correct target language rule but uses it inconsistently (cited in Ellis, 1994).

Dulay, Burt, and Krashen (1982) established four broad classifications of errors: (1) linguistic taxonomy which classifies errors according to the language component and the particular linguistic constituent the error affects; (2) surface strategy taxonomy which emphasizes the ways surface structures are changed; (3) comparative analysis taxonomy which is based on comparison between the structures of L2 errors and certain other types of construction; (4) communicative effect taxonomy focuses on the effect of errors on the listener or reader.

Regarding linguistic taxonomy, Keshavarz (1999) classified errors into four distinct categories: orthographic errors, phonological errors, lexico-semantic errors, and syntactic-morphological errors (cited in Nayernia, 2011). Corder (1973) classified errors based on the main processes which lead to erroneous utterances: omission, addition, substitution and permutation (misordering). Dulay et al. (1982) classified errors according to the ways the surface structure is altered in erroneous utterances: omission, addition, misformation (substitution) and misordering. The two taxonomies proposed by Corder (1973) i.e. processing errors, and Dulay et al. (1982) i.e. surface errors, are compatible and their subcategories can be equated. Omission errors refer to the absence of an item that must appear in a well-formed utterance. Addition errors refer to the presence of an item that must not appear in a well-formed utterance. Misformation or substitution errors are due to the use of the wrong form, morpheme or structure. Misordering errors are due to the incorrect placement of a morpheme or a group of morphemes in an utterance.

Based on communicative effect taxonomy, Burt and Kiparsky (1972) distinguished between global and local errors. Global errors hinder communication, and prevent the utterance from being understood, but local errors do not cause problems of comprehension. Corder (1973) distinguished between two types of covert and overt errors. 
Covertly erroneous utterances are grammatically correct and well formed at the sentence level but unaccepted within the context of communication. They do not convey the addresser's intention. Overtly erroneous utterances, on the contrary, are ungrammatical at the sentence level. They are easily observable in the surface structure of a sentence.

Sarosdyand and Tamas (2006) made a distinction between qualitative and quantitative errors. Qualitative errors impede communication or distort the information transferred but quantitative errors do not affect communication (cited in Abbasi \& Karimnia, 2011). Camps, Villalobos, and Shea (2012) categorized language learners' errors in to three types: errors understood by the native speaker, errors not understood by the native speaker, and errors misunderstood by the native speaker.

\subsection{Pedagogical Implications of EA}

Language teaching cannot stand away from the findings of EA. Analysis of learners' errors has positive effects on teaching-learning process. EA studies are carried out first, to identify strategies which learners use in language learning, second, to recognize the causes of learners' errors and third to obtain information on common difficulties in language learning as an aid to teaching or in development of teaching materials (Richards et al., 1992). According to Keshavarz (1999) EFL teachers, syllabus designers, and test constructors, benefit from EA. By analyzing learners' errors, teachers can come to a better understanding of the problematic areas for learners, and they can evaluate the effectiveness of their teaching techniques and materials as well. Therefore, using more efficient teaching techniques and strategies, they can focus on these problematic areas. EA can provide good information for syllabus designers and material developers. Considering students' difficulties and errors, syllabus designers can concentrate on these parts.

Another pedagogical implication of error analysis is error correction and attitudes towards errors (ibid). Types and sources of errors determine the kind of feedback and treatment and also help teachers employ efficient teaching strategies when facing an error. Harmer (1998) suggested three steps to be followed by the teacher when errors occur: first listening to the student, then identifying the problem and third putting the error right in the most efficient way. Erdogan (2005) suggested that a hierarchy of errors should be established so that teacher can focus on the errors which may affect communication and cause misunderstanding. In a nutshell, efficient teaching techniques and strategies as well as proper material are needed to remove students' problems in learning. For this reason, problematic areas must be examined and investigated carefully and clearly. Therefore error analysis is needed.

According to Yaghoubi (2009) not only teachers but also learners need some strategies to face the errors so that teachers can correct learners' errors properly and learners can trace their own errors and use proper strategies in the domain of error monitoring and error orientation. Error orientation shows how learners cope with and react to their own errors (Rybowiak, et al., 1999). EA fills the gap between language learning and teaching, and contributes to learner-centered language pedagogy by making the teaching techniques closer to the learning strategies (Mahmoud, 2011).

\subsection{Gender and EA}

In the last decades, many studies on the existence and nature of differences between men and women from different perspectives have been carried out, and language as a social phenomenon hasn't been an exception. Men and women tend to function differently in their brain and language function may be more organized in women (Dingwall, 1998 cited in Chiu, 2008). Larsen-Freeman and Long (1991) claimed that females are better than males in first and second language acquisition. Oxford et al. (1993) reported higher mean scores for females than males in a Japanese language class. In her study, Salem (2006) found significant differences between males and females in their use of memory, cognitive and compensation strategies, in favor of females.

Newman et al. (2008) found small but systematic differences in the way that men and women use language, 
both in terms of what they say and how they choose to say it. After an empirical study in a university, Yan (2009) came to the conclusion that obvious gender differences exist among male and female students in second language learning and that female students have language advantages. Hamdi Asl and Dabaghi (2012) found gender differences in Iranian EFL learners' letter writing. In her study, Zeynali (2012) found that female learners tend to use social/affective strategies more frequently than male learners.

As Ellis (1985) stated, analysis of learners' errors leads to the understanding of language learning process. "Errors are systematic deviations from the norms of the language being learned" (Cunningworth, 1987, p. 87); Therefore, EA is a systematic study. EA informs us about the strategies learners employ to develop their competence in the target language, therefore analysis of EFL learners' errors based on their gender can lead to information on the underlying process of second or foreign language learning in the two sexes.

Although the issue of gender differences has received considerable attention in the context of second or foreign language learning and teaching, few studies on the relationship between gender and EFL learners' written errors have been carried out and the impact of learners' gender, as a constant learner variable, on the rate, types and sources of errors has not received much attention.

\subsection{Research Questions}

Following surface taxonomy and linguistic taxonomy proposed by Dulay et al. (1982), in the present study two types of errors were considered with their subcategories, namely processing errors (surface errors) with four subcategories, i.e. omission, addition, substitution and misordering, and syntactic errors with six subcategories, i.e. misuse of singular/plural, misuse of articles, misuse of prepositions, subject/verb disagreement, wrong verb tense, and wrong verb construction. This study is an attempt to investigate these error types in the two sexes; To achieve this aim, the following research questions will be explored:

1. Are there any significant differences between the frequencies of processing errors committed by advanced EFL male/female learners in their writing papers? (Omission, addition, substitution, misordering).

2. Are there any significant differences between the frequencies of different types of grammatical errors in written productions of advanced EFL male/ female learners? (Misuse of singular/plural, misuse of articles, misuse of prepositions, subject/verb disagreement, wrong verb tense, wrong verb construction).

\section{Method}

\subsection{Participants}

100 advanced EFL learners (50 male students \& 50 female students), who had studied English for years in an English Institute in Kerman (a city in south east of Iran), with the same syllabus, material, and teaching methodology, took part in the study. These students were all Iranian and native speakers of Persian. They were chosen by random sampling. Their writing papers were collected, corrected and analyzed by the researchers.

\subsection{Instruments}

A total of 100 learners' writing papers were gathered randomly. These writing papers had been written by advanced EFL learners (50 female students \& 50 male students) on the same topic.

\subsection{Procedure}

A total of 200 writing papers on one subject were collected. These writing papers were written by 100 male 
A gender-based analysis of Iranian EFL learners' types of written errors

learners and 100 female learners who studied English as a foreign language at advanced levels in an English institute in Kerman, a city in south east of Iran. The papers were then numbered by the researchers from 1 to 100 in each group of male and female learners, and then the ones with the odd numbers were selected and corrected. The errors extracted from 100 writing papers (50 papers written by male learners and 50 papers written by female learners) were identified and categorized according to their types, and at last they were analyzed by statistical tests. Based on learners' errors, chi square test investigated if there were any significant differences among the frequencies of different subdivisions in each category and then the types of errors in the two groups of male learners and female learners were compared by use of Pearson Chi-Square test (Cross-Tab).

\section{Results}

\subsection{Subdivisions of error types}

Chi-Square test was used to reveal the distribution of subdivisions of different types of errors committed by advanced learners in their writing papers.

\section{Table 1}

Advanced EFL male learners' processing errors in their writing papers

\begin{tabular}{|c|c|c|c|c|c|}
\hline $\begin{array}{c}\text { Males' processing } \\
\text { errors }\end{array}$ & Frequency & Percent & $\begin{array}{c}\text { Chi-Square } \\
\text { (a) }\end{array}$ & df & $\begin{array}{c}\text { Asymp. Sig. } \\
\text { (p-value) }\end{array}$ \\
\hline Omi & 163 & 45.0 & & & \\
\hline Add & 47 & 13.0 & & & \\
\hline Sub & 132 & 36.5 & 152.939 & 3 & 0.000 \\
\hline Mis & 20 & 5.5 & & & \\
\hline Total & 362 & 100.0 & & & \\
\hline
\end{tabular}

According to table 1, among 362 processing errors committed by advanced male learners, 163 errors (45\%) were omission, 47 errors (13\%) were addition, 132 errors (36.5\%) were substitution and 20 errors $(5.5 \%)$ were misordering. Based on Chi-Square test $\mathrm{p}$-value is 0 which is less than the significance level $(\alpha=0.05)$. Therefore there are meaningful differences among the frequencies of male learners' processing errors subdivisions. Considering the percentages of different types of processing errors, it can be concluded that omission and misordering were respectively the most and the least processing errors committed by advanced male learners.

Table 2

Advanced EFL female learners' processing errors in their writing papers

\begin{tabular}{cccccc}
\hline $\begin{array}{c}\text { Females' processing } \\
\text { errors }\end{array}$ & Frequency & Percent & $\begin{array}{c}\text { Chi-Square } \\
\text { (a) }\end{array}$ & df & $\begin{array}{c}\text { Asym. Sig. } \\
\text { (p-value) }\end{array}$ \\
\hline Omi & 288 & 49.8 & & \\
Add & 98 & 17.0 & & 0.000 \\
Sub & 177 & 30.6 & 280.837 & 3 & \\
Mis & 15 & 2.6 & & \\
\hline Total & 578 & 100.0 & \\
\hline Note. "Omi" stands for omission. "Add" stands for addition. "Sub" stands for substitution. "Mis" stands for misordering.
\end{tabular}

According to table 2, among 578 processing errors committed by advanced female learners, 288 errors $(49.8 \%)$ were omission, 98 errors (17\%) were addition, 177 errors $(30.6 \%)$ were substitution and 15 errors $(2.6 \%)$ were misordering. Based on Chi-Square test $\mathrm{p}$-value is 0 which is less than the significance level $(\alpha=0.05)$. 
Boroomand, F. \& Rostami Abusaeedi, A. A.

Therefore there are meaningful differences among the frequencies of subdivisions of female learners' processing errors. Considering the percentages of different types of processing errors, it can be concluded that omission and misordering were respectively the most and the least processing errors committed by advanced female learners.

Table 3

Advanced EFL male learners' syntactic errors in their writing papers

\begin{tabular}{|c|c|c|c|c|c|}
\hline $\begin{array}{c}\text { Males' syntactic } \\
\text { errors }\end{array}$ & Frequency & Percent & $\begin{array}{c}\text { Chi-Square } \\
\text { (a) }\end{array}$ & $\mathrm{df}$ & $\begin{array}{r}\text { Asym. Sig } \\
\text { (p-value) }\end{array}$ \\
\hline MSinPlu & 90 & 29.6 & & & \\
\hline MArt & 45 & 14.8 & & & \\
\hline MPre & 48 & 15.8 & & & \\
\hline SVDis & 45 & 14.8 & 39.263 & 5 & 0.000 \\
\hline WVTen & 33 & 10.9 & & & \\
\hline WVCon & 43 & 14.1 & & & \\
\hline Total & 304 & 100.0 & & & \\
\hline
\end{tabular}

According to table 3, among 304 syntactic errors, committed by advanced male learners, 90 errors $(29.6 \%)$ were misuse of singular/plural, 45 errors $(14.8 \%)$ were misuse of articles, 48 errors (15.8\%) were misuse of prepositions, 45 errors (14.8\%) were subject/verb disagreement, 33 errors (10.9\%) were wrong verb tenses, and 43 errors $(14.1 \%)$ were wrong verb constructions. Based on Chi-Square test, p-value is 0 which is less than the significance level $(\alpha=0.05)$. Therefore there are significant differences among the frequencies of subdivisions of male learners' syntactic errors. Considering the percentages of different types of syntactic errors, it can be concluded that misuse of singular/plural and wrong verb tense were respectively the most and the least types of syntactic errors committed by advanced male learners.

\section{Table 4}

Advanced EFL female learners' syntactic errors in their writing papers

\begin{tabular}{|c|c|c|c|c|c|}
\hline $\begin{array}{l}\text { Females' syntactic } \\
\text { errors }\end{array}$ & Frequency & Percent & $\begin{array}{l}\text { Chi-Square } \\
\text { (a) }\end{array}$ & $\mathrm{df}$ & $\begin{array}{l}\text { Asym. Sig. } \\
\text { (p-value) }\end{array}$ \\
\hline MSinPlu & 200 & 40.4 & \multirow{6}{*}{211.897} & \multirow{6}{*}{5} & \multirow{6}{*}{0.000} \\
\hline MArt & 75 & 15.2 & & & \\
\hline MPre & 67 & 13.5 & & & \\
\hline SVDis & 62 & 12.5 & & & \\
\hline WVTen & 35 & 7.1 & & & \\
\hline WVCon & 56 & 11.3 & & & \\
\hline Total & 495 & 100.0 & & & \\
\hline \multicolumn{6}{|c|}{$\begin{array}{l}\text { Note. "MSinPlu" stands for misuse of singular/plural. "MArt" stands for misuse of articles. "MPre" stands for misuse of prepositions. } \\
\text { "SVD" stands for subject/verb disagreement. "WVTen" stands for wrong verb tense. "WVCon" stands for wrong verb construction. }\end{array}$} \\
\hline \multicolumn{6}{|c|}{$\begin{array}{l}\text { According to table } 4 \text {, among } 495 \text { syntactic errors, committed by advanced female learners } 200 \text { errors }(40.4 \%) \\
\text { e misuse of singular/plural, } 75 \text { errors }(15.2 \%) \text { were misuse of articles, } 67 \text { errors }(13.5 \%) \text { were misuse of } \\
\text { positions, } 62 \text { errors }(12.5 \%) \text { were subject/verb disagreement, } 35 \text { errors }(7.1 \%) \text { were wrong verb tenses, and } 56 \\
\text { ors }(11.3 \%) \text { were wrong verb constructions. Based on Chi-Square test, p-value is } 0 \text { which is less than the } \\
\text { hificance level }(\alpha=0.05) \text {. Therefore there are significant differences among the frequencies of subdivisions of } \\
\text { rale learners' syntactic errors. Considering the percentages of different types of syntactic errors, it can be } \\
\text { cluded that misuse of singular/plural and wrong verb tense were respectively the most and the least types of } \\
\text { tactic errors committed by advanced female learners. }\end{array}$} \\
\hline
\end{tabular}




\subsection{Male and female learners' types of errors}

Pearson Chi-Square test was used to contrast the frequencies of different types of written errors in the two groups of advanced EFL male and female learners, and find out if there were any significant differences between these groups regarding the frequencies of their types of written errors.

Table 5

Contrasting advanced EFL male and female learners' processing errors

\begin{tabular}{ccccccc}
\hline Processing errors & Male & Female & Total & $\begin{array}{c}\text { Pearson } \\
\text { Chi-Square }\end{array}$ & $\begin{array}{c}\text { Asymp. Sig. } \\
(\mathrm{p} \text {-value })\end{array}$ \\
\hline Omi & 163 & 288 & 451 & & \\
Add & 47 & 98 & 145 & & 0.013 \\
Sub & 132 & 177 & 309 & $10.786(\mathrm{a})$ & 3 & \\
Mis & 20 & 15 & 35 & & \\
\hline Total & 362 & 578 & 940 & & \\
\hline Note. "Omi" stands for omission. "Add" stands for addition. "Sub" stands for substitution. "Mis" stands for misordering.
\end{tabular}

According to table 5, based on Pearson Chi-Square test, p-value is 0.013 which is less than the significance level $(\alpha=0.05)$. Therefore, there are meaningful differences between the two groups of advanced male and female learners, regarding their processing errors. Contrasting frequencies of different types of processing errors in the two groups shows that, female learners committed more omission, addition, and substitution errors than male learners.

While, according to table 6, based on Pearson Chi-Square test, p-value is 0.037 which is less than the significance level $(\alpha=0.05)$. Therefore, there are meaningful differences between the two groups of advanced male and female learners, regarding their syntactic errors. Contrasting the frequencies of different types of syntactic errors in the two groups shows that female learners committed more errors regarding all types of syntactic errors than male learners.

\section{Table 6}

Contrasting advanced EFL male and female learners' syntactic errors

\begin{tabular}{lccccc}
\hline Syntactic errors & Male & Female & Total & $\begin{array}{c}\text { Pearson } \\
\text { Chi-Square }\end{array}$ & $\begin{array}{c}\text { Asymp. Sig. } \\
\text { (p-value) }\end{array}$ \\
\hline MSinPlu & 90 & 200 & 290 & & \\
MArt & 45 & 75 & 120 & & \\
MPre & 48 & 67 & 115 & 11.849 (a) & \\
SVDis & 45 & 62 & 107 & & \\
WVTen & 33 & 35 & 68 & \\
WVCon & 43 & 56 & 99 & \\
\hline Total & 304 & 495 & 799 & \\
\hline Note: "MSinPlu" stands for misuse of singular/plural. "MArt" stands for misuse of articles. "MPre" stands for misuse of prepositions. \\
"SVD" stands for subject/verb disagreement. "WVTen" stands for wrong verb tense. "WVCon" stands for wrong verb construction.
\end{tabular}

\section{Conclusion}

Running Chi-Square test on errors extracted from advanced learners' writing papers, revealed distribution of different subdivisions of different types of errors in their writing papers. In all classifications (processing errors and syntactic errors), $p$-values for the different subdivisions were less than the significance level $(\alpha=0.05)$; Therefore, there were meaningful differences among the distribution of different subdivisions in each classification of errors. Namely, among processes which lead to errors, omission and substitution had the most impact on advanced learners' error commitment respectively, and misuse of singular/plural was the most 
committed error type among the syntactic types analyzed in this study. In other words, advanced EFL learners have serious difficulties in conveying plurality. Misuse of articles, misuse of prepositions, and subject/verb disagreement were their major difficulties as well. The results of the present study correspond to what Talif and Edwin (1989) found in their research. They stated that in addition to verb forms, EFL learners have difficulties in plurality, ranked the highest, followed by articles, prepositions, and subject/verb disagreement.

Pearson Chi-Square test, contrasted the frequencies of different classifications of errors in the two groups of male and female learners. Regarding the p-values for processing errors and syntactic errors in the two groups which were less than the significance level $(\alpha=0.05)$, it is concluded that there are significant differences between the two groups of males and females, considering processing errors and syntactic errors. Despite some researches done by different researchers which reveal female language learners commit less writing errors, show more improvement in writing over time or gain higher writing scores than male learners (Chen, 1996, Abu-Jarad, 2008, Chiu, 2008, Al-Nawas, 2009), the present study reveals more error commitment by female learners.

\subsection{Implications of the study}

Along with teachers, learners, syllabus designers, material developers and researchers can benefit from the results of the present study. Detecting the most frequent types of grammatical errors, this study contains diagnostic information about problematic areas at advanced levels. Diagnosis of errors and employing effective feedback and teaching strategies and techniques is essential for language teachers. Being aware of types and causes of errors committed by advanced EFL learners, is vital for both teachers and learners. Making advanced EFL students aware of their most problematic areas can encourage them to concentrate on these errors and improve their writing (Tahririan, 1986). Additionally, teachers need to be aware of dissimilarities between genders in pedagogical contexts so that they can provide male and female learners with appropriate assistance to facilitate learning. Considering the most problematic areas, syllabus designers and material developers can prepare systematic syllabuses and provide remedial material for learners. Researchers can employ the findings of such a gender-based analysis in other fields of language studies.

\subsection{Limitations of the study and Suggestions for future studies}

The present study suffers from some limitations. First, the study was limited to a few categories and subcategories for types of errors, i.e. processing errors with four subcategories and syntactic errors with six subcategories were considered. In regard to error types, errors related to different linguistic components such as semantics, morphology, lexicon and orthography were neglected. Second, the number of participants was limited. Third, the results of the study were based on errors extracted from participants' writing papers. It is doubtful whether the collected writing papers can be accepted as the real output of the learners. The reason is that they had to limit their writing to the specific topic so their writing might not show their exact ability in language written production, and also the rate of their productivity might vary in different situations and at different times. Therefore repetition of the same study with more participants is suggested.

The findings of this study call for more researches in the field of error analysis regarding the two sexes. Such a gender-based error analysis can be re-conducted at elementary and intermediate levels. Some gender-based analyses can be carried out on different error types as well as error sources of advanced EFL learners in different kinds of writing (narrative, descriptive and expository). The researchers, who are interested in analyzing learners' errors, can conduct gender-based error analyses and employ the findings in other studies which put learners' language learning strategies and psychological as well as socio-cultural factors under question in the two sexes. For example, error orientation which is the reaction of language learners to their own errors can be studied in the two sexes.

\section{References:}

Abbasi, M., \& Karimnia, A. (2011). An analysis of grammatical errors among Iranian translation students: 
A gender-based analysis of Iranian EFL learners' types of written errors

Insights from interlanguage theory. European Journal of Social Sciences, 25(4), 525-536.

Abu-Jarad, H. A. (2008). Evaluating grammar development through longitude error analysis of English major students. Al-Azhar University. Jame'at Alaqsa Journal, 12(2), 54-68.

Alhaysony, M. (2012). An analysis of article errors among Saudi female EFL students: A case study. Asian Social Science, 8(12), 55-66. http://dx.doi.org/10.5539/ass.v8n12p55

Al-Nawas, R. S. (2009). English texts written by advanced Iraqi learners: An overview in error analysis and corpus linguistics. Paper presented at the $4^{\text {th }}$ international English language teaching conference. Penang, Malaysia.

Burt, M., \& Kiparsky, C. (1972). The gooficon: A repair manual for English. Rowley, MA: Newbury House.

Camps, D., Villalobos, J., \& Shea, J. (2012). Understanding EFL students' errors: An insight towards their interlanguage. MEXTESOL Journal, 36(1), 1-14.

Chen, J. F. (1996). Gender differences in Taiwan business writing errors. The Internet TESL Journal, 2(10). Retrieved May 26, 2013, from http://iteslj.org/Articles/Chen-GenderDifs/

Chiu, C. (2008). An investigation of gender differences in EFL college writing. Proceedings of the BAAL annual conference 2008 (pp. 25-26). Retrieved May 26, 2013, from http://www.baal.org.uk/proc08/chiu.pdf

Corder, S. P. (1967). The significance of learners' errors. IRAL, 5, 161-170. http://dx.doi.org/10.1515/iral.1967.5.1-4.161

Corder, S. P. (1971). Idiosyncratic dialects and error analysis. IRAL, 9(2), 147-159. http://dx.doi.org/10.1515/iral.1971.9.2.147

Corder, S. P. (1973). Introducing applied linguistics. Penguin Education.

Corder, S. P. (1974). Error analysis. Oxford: Oxford University Press.

Cunningworth, A. (1987). Evaluation and selecting EFL teaching materials. London: Heinemann Education Book.

Darus, S., \& Subramaniam, K. (2009). Error analysis of the written English essays of secondary school students in Malaysia: A case study. European Journal of Social Sciences, 8(3), 483-495.

Dessouky, S. (1990). Error analysis: A non-stop area of research. Studies in Curricula and Methodology, 8, 146-176.

Dingwall, W. O. (1998). The biological bases of human communication behavior. In J. B.Gleason \& N. B. Ratner (Eds.), Psycholinguistics (pp. 51-105). Fort Worth: Harcourt Brace College Publishers.

Dulay, H., Burt, M., \& Krashen, S. (1982). Language two. New York: Oxford University Press.

Ellis, R. (1985). Understanding second language acquisition. Oxford, UK: Oxford University Press.

Ellis, R. (1994). The study of second language acquisition. London: Oxford University Press.

Erdogan, V. (2005). Contribution of error analysis to foreign language teaching. Mersin University Journal of the Faculty of Education, 1(2), 261-270.

Gustilo, L., \& Magno, C. (2012). Learners' errors and their evaluation: The case of Filipino ESL writers. Philipine ESL Writers, 8, 96-112.

Halliday, M. A. K., McIntosh, A., \& Strevens, P. (1964). The linguistic sciences and language Teaching. London: Longman.

Hamdi Asl, S., \& Dabaghi, A. (2012). Gender differences in Iranian EFL students' letter writing. International Journal of Applied Linguistics \& English Literature, 1(7), 155- 169. http://dx.doi.org/10.7575/ijalel.v.1n.7p.155

Harmer, J. (1998). How to teach English. Essex. Longman.

Jabbari, A. A. \& Fazilatfar, A. M. (2012). The role of error types and feedback in Iranian EFL classrooms. International Journal of English Linguistics, 2(1), 135-148. http://dx.doi.org/10.5539/ijel.v2n1p135

Jalali, H., \& Shojaei, M. (2012). Persian EFL students' developmental versus fossilized prepositional errors. The Reading Matrix, 12(1), 80-97.

Jie, X. (2008). Error theories and second language acquisition. US-China Foreign Language, 6(1), 35-42.

Jiménez Catalán, R. (1997). Terms and definitions of errors in SLA. Bells: Barcelona English language and literature studies, 8, 60-81.

Keshavarz, M. H. (1999). Contrastive analysis and error analysis. Tehran: Rahnama Publications. 
Boroomand, F. \& Rostami Abusaeedi, A. A.

Khodabandeh, F. (2007). Analysis of students' errors: the case of headlines. The Asian ESP Journal, 3(1), 6-21.

Larsen-Freeman, D., \& Long, M. (1991). An introduction to second language acquisition research. London: Longman.

Mahmoud, A. (2011). The role of interlingual and intralingual transfer in learner-centered EFL vocabulary instruction. Arab World English Journal, 2(3), 28-47.

Mohaghegh, H., Mahmoudi Zarandi, F., \& Shariati, M. (2011). Grammatical errors produced by English majors: The translation task. Educational Research and Reviews, 6(16), 877-888.

Nayernia, A. (2011). Writing errors, what they can tell a teacher? MJAL, 3(2), 200-217.

Newman, M. L., Groom, C. J., Handelman, L. D., \& Pennebaker, J. W. (2008). Gender differences in language use: An analysis of 14,000 text samples. Discourse Processes, 45, 211-236. http://dx.doi.org/10.1080/01638530802073712

Nezami, A., \& Sadraie Najafi, M. (2012). Common error types of Iranian learners of English. English Language Teaching, 5(3), 160-170. http://dx.doi.org/10.5539/elt.v5n3p160

Oxford, R., Young, P. O., Ito, S., \& Sumrall, M. (1993). Japanese by satellite: Effects of motivation, language learning styles and strategies, gender, course level, and previous language learning experience on Japanese language achievement. Foreign language annals, 26, 359-371. http://dx.doi.org/10.1111/j.1944-9720.1993.tb02292.x

Pena, S. (2009). Analysis of errors in the essays written by math, science and engineering faculty. Liceo Journal of Higher Education Research, 6(1), 76-85.

Richards, J. C., Platt, J., \& Platt, H. (1992). Longman dictionary of language teaching and applied linguistics. England: Longman House, Essex.

Rybowiak, V., Garst, H., Frese, M., \& Batinic, B. (1999). Error orientation questionnaire (EOQ): Reliability, validity, and different language equivalence. Journal of Organizational Behavior, 20, 527- 547. http://dx.doi.org/10.1002/(SICI)1099-1379(199907)20:4<527::AID-JOB886>3.0.CO;2-G

Salem, N. M. (2006). The role of motivation, gender, and language learning strategies in EFL proficiency. Unpublished thesis. American University of Beirut.

Sarosdy, F. \& Tamas, B. (2006).Applied Linguistics for BA Students in English. Bolcsesz Konzorcium: Minden Jog Fenntartva.

Selinker, L. (1972). Interlanguage. IRAL, 10(3), 209-231. http://dx.doi.org/10.1515/iral.1972.10.1-4.209

Tahririan, M. H. (1986). Error awareness and advanced EFL learner's performance. RELC Journal, 17(2), 41-54. http://dx.doi.org/10.1177/003368828601700203

Talif, R., \& Edwin, M. (1989). Error analysis of form four English compositions. The English teacher, XVIII. Retrieved from http://www.melta.org.my/ET/1989/main9.html

Watcharapunyawong, S., \& Usaha, S. (2013). Thai EFL students' writing errors in different text types: The interference of the first language. English Language Teaching, 6(1), 67-78.

Wee, R. (2009). Sources of errors: An interplay of interlingual influence and intralingual factors. European Journal of Social Sciences, 11(2), 349-359.

Yaghoubi, A. (2009). Error competence and structural competence in EFL context. The Journal of Modern Thoughts in Education, 4(4), 91-110.

Yan, H. (2009). Empirical study on relations between gender differences and English vocabulary and the overall proficiency level. Asian Social Science, 5(10), 109-114.

Yazdani, P., \& Ghafar Samar, R. (2010). Involved or informative: A gender perspective on using pronouns and specifiers in EFL students' writing. MJAL, 2(5), 354-378.

Zeynali, S. (2012). Exploring the gender effect on EFL learners' learning strategies. Theory and practice in language studies, 2(8), 1614-1620. 
Appendix

Some errors committed by advanced male and female learners in their writing papers

1. Misuse of singular / plural

a. Omission

-Students' score are considered ....

-Some other animal have this kind of sense....

-Using letter is not a fast way.

b. Addition

-You must take medicines.

-It's a gift from that times.

-Soaps are in the bathroom.

c. Substitution

-Giraffes eat the leafs.

-The childs are in the yard.

-He was scared of the wolfs.

2. Misuse of articles

a. Omission

-If you do not find _ _ quiet place to study, ...

- _ Man in gray suit ordered coffee.

- They were making _ _ movie about Iranian culture.

- That was__ first time we met.

b. Addition

- There is a lot of potassium in the bananas.

- The plants need water to grow up.

- The boy needed a glue to make a kite.

c. Substitution

- I got some information about an special thing.

- They have a unrealistic solution for the problem.

- The cold is a common disease in winter months which ....

3. Misuse of prepositions

a. Omission

- They wanted to connect_internet...

- I like both _ the games.

- We came back home_ Friday. 
b. Addition

- I helped to my mother do the housework.

- The rapid increase of prices effects on people's lives.

- We called to the police after the accident.

c. Substitution

- We watched the candidates' debate in TV.

- The rude boy threw stones to us.

- I was thinking to the soccer game when the teacher came in.

\section{Subject / verb disagreement}

- Their mother have a part time job.

- A number of old books is in the library.

- Mary like cookies.

\section{Wrong verb tense}

- I go to a kindergarten when I was five.

-We knew that we can't find them.

- They were tired and they sleep all day.

6. Wrong verb construction

- Letters may not deliver to the destination ...

- They have living here for 5 years.

- Air pollution growing fast.

\section{d. Misordering}

- Our teacher explains the lessons always kindly.

- They in the yard were playing basketball.

- She very well could make crafts. 